\title{
VOCABULARY ENHANCEMENT THROUGH MEMRISE AND GOOGLE CLASSROOM
}

\author{
Stephanie Feli Taebenu, Caroline Victorine Katemba \\ Universitas Advent Indonesia (UNAI), Bandung, Indonesia \\ E-mail: ctobing@unai.edu
}

Received: 2021-05-30

Accepted: 2021-06-21

\begin{abstract}
Google Classroom is one of the most used learning platforms during this Covid-19 pandemic at school, especially in Indonesia. Besides that, another application is used to make the English classes attractive and interesting. Memrise application is used in this study as an addition to google classroom. Therefore, the purpose of this study is to see if there is a significant difference in vocabulary enhancement between females and males using Google Classroom and Memrise. This study employed a quantitative research method and a comparative design with pre-test and post-test. The sample size for this study was 40 students. The students were divided into two groups, with those two groups there were 20 female and 20 male students. The result of this study showed that both groups of students could enhance their vocabulary ability but, the female group result showed a significantly higher enhancement compared to the male group. Another result showed there was a significant difference in vocabulary enhancement between students who were taught using Memrise through Google Classroom in the female and male groups. In summary, the findings indicated that Memrise was effective in helping students to enhance and enrich their vocabulary.
\end{abstract}

Keywords: Educational Technology, CALL (Computer Assisted Language Learning), MALL (Mobile Assisted Language Learning)

\section{Introduction}

Male and female students all learn through the same approach and lesson together in the same classroom, doing the same activity with the same teacher and being treated equally. Nevertheless, male and female students are different, and they are behaving differently at schools. Male and female are not mentally and physically different, but they also have different abilities to memorize vocabulary in the English language (Wei, 2016).

Gender usually catches the attention of researchers, though, in the number of studies fulfilled on relatively small topics (Catalán, 2003). Each male and female has their learning style when it comes to a learning method that is appropriate for their ability (Natsir et al., 2016). Vocabulary learning looks to be an area where gender can be thought about as a distinctive issue (Boyle, 1987). Aside from that, gender is thought to be one of the important affectional factors that play a specific role and influence second language acquisition (Zoghi et al., 2013).

Language is also closely related to learning because the most important aspect of learning languages is the learning methods, and language is the key to the method of 
Vocabulary Enhancement through Memrise \& Google Classroom, Stephanie Feli Taebenu, Caroline Victorine Katemba

learning (Mehrabian, Salehi, \& Branch, 2019). In learning English, one of the most important skills to have is a good vocabulary. Vocabulary is defined broadly as the knowledge of words and their meanings. More precisely, we use vocabulary to check the types of words that students should understand to read more and more exacting text with comprehension (Nurdiansyah et al., 2019).

Vocabulary is a fundamental and necessary skill that must be mastered when attempting to learn another language (Sari \& Sutopo, 2018). There are three elements got to be noted in learning English: vocabulary, grammar, and pronunciation, and vocabulary is the crucial part of learning English (Beglar \& Hunt, 2005).

In other words, the process of learning a new or foreign language requires a strong command of vocabulary (Giessen, 2019). As stated by Korlu \& Mede (2018), vocabulary and learning are two interconnected units that cannot be separated. Learning vocabulary will make it easier to understand the four English skills, such as listening, speaking, reading, and writing (Indrasari, Novita, \& Megawati, 2018). As stated by Krashen \& Terrell (1983), learners cannot master English while not mastering the vocabulary. Communication among students while learning, directing thoughts, opinions, and knowledge is made less difficult if the vocabulary has been properly studied (Aisyah et al., 2019). Vocabulary should be wellmastered to support their ability to speak and be ready to act with others, either orally or in writing, so that their messages are delivered without miscommunication. In that case, mastering vocabulary will facilitate students to enhance their English skills.

In Indonesia, students have difficulty mastering vocabulary. "Indonesian students often experience problems when learning English, specifically vocabulary, because English differs from Bahasa Indonesia (the Indonesian language) in its structure, pronunciation, and vocabulary" (Katemba, 2019, p. 88). That is why various studies and several methods have been conducted to improve vocabulary knowledge (Ning, 2017; Rumondor, 2017; Katemba, 2019; Katemba \& Sianipar, 2020; Katemba, 2021; Berliani \& Katemba, 2021). The teachinglearning method has some flaws, particularly in vocabulary learning. The flaws mean the students' problems include a lack of motivation to learn vocabulary, a poor understanding of the English language, and difficulty translating English sentences. Nunan (1991), claims that motivation is significant in learning accomplishment. Meanwhile, teachers continue to use standard teaching strategies, where only English texts are provided by the teacher, and students are instructed to use a dictionary to translate. This method is tedious for students and necessitates more time spent learning the given sentence. To improve students' vocabulary, a teacher should have something to influence students to be more confident and more active in learning vocabulary (Chun, Kern, \& Smith, 2016). In addition, a teacher should be looking for a fun way to create a new atmosphere so that students can learn English in a fun and enjoyable way.

To overcome these challenges, teachers should vary their methods of assisting the students to increase their vocabulary knowledge. Researchers have selected an up-to-date method for teaching vocabulary is through the Memrise application. The Memrise application was used on both males and females which is considered an effective approach to improve and enhance the students' vocabulary. These methods are proven capable to increase students' vocabulary knowledge. And the benefits of using technology in the classroom can help teachers work with students more easily especially during this pandemic time.

Abrams \& Walsh (2014); Berliani \& Katemba (2021) found that using technology-based games for vocabulary instruction could enhance students' vocabulary assessment scores. 
Aminatun \& Oktaviani (2019) claimed from their study that Memrise: Promoting Students' Autonomous Learning Skill through Language Learning Application. The result of this study stated that Memrise was an effective method to improve students' ability to learn independently outside of the classroom, particularly when studying English. Widyaningrum \& Putro (2020) in their study used Memrise to promote students' listening and speaking abilities. Their research found that Memrise also played an important role in enhancing students' listening and speaking skills.

In the educational world, gamification is a method of engaging students in inventive classroom games without putting at risk the curriculum's scientific nature (Nolan \& McBride, 2014). Gamification encourages students to develop critical thinking and multitasking skills in an educational setting (Kapp, 2012; Prensky, 2001). Gamification can make teaching and learning more enjoyable and also increase student motivation to learn (Muntean, 2011).

Memrise grows rapidly and now more than 50 million people in various countries around the world are learning languages with this application. According to Karjo and Andreani (2018), Memrise is a vocabulary-building online learning platform, and Memrise was founded by Ed Cooke and Greg Detre. This app offers over 150 language courses in 25 languages, including English, Korean, French, Spanish, Japanese, German, Russian, Chinese, Vietnamese, Portuguese, Swedish, Norwegian, Danish, Arabic, Dutch, Indonesian, Italian, Polish, and Turkish. Furthermore, the layout of Memrise is nearly identical to that of the Duolingo application. Memrise is an educational tool that allows you to study a variety of subjects online and on mobile devices (Luczak, 2017). Students can use Memrise to learn various aspects and specifications, such as vocabulary, grammar, and so on, when learning the language in particular. Besides using Memrise in teaching vocabulary, another learning platform that the researchers use is Google Classroom.

Since August 12, 2014, Google Classroom has been included as part of Google Apps for Education (GAFE). Google Classroom is a product of Google that integrates with g-drive, gmail, immersive calendar, hangouts, and youtube. The tools of Google Classroom will make it easier for teachers to conduct learning activities. Learning is intended to take place not only in the classroom but also outside of it, as students can access Google online classes from anywhere and at any time. Google Classroom will serve as a platform for blended learning in schools, making it easier to create assignments and distribute grades to students in a paperless environment (Iftakhar, 2016). These are well-known Web tools that offer a wide range of useful features and applications. Because of its unique innate functions that provide pedagogical, social, and technological capabilities, it, like many other Web tools, has the potential to be used for teaching and learning (Abid Azhar \& Iqbal, 2018).

\section{Literature Review}

This literature review provides an overview of the research, which consists of vocabulary, challenges in improving vocabulary games, teaching vocabulary, teaching vocabulary through quiz games, and a conceptual framework.

\subsection{Vocabulary}

In this part, the researchers concern with the theories of vocabulary achievement that affect the students' ability in learning vocabulary and discuss teaching vocabulary through Memrise application. 
"Vocabulary can be defined as words that we should know to communicate effectively; words in expressive vocabulary for speaking and words in receptive vocabulary for listening" (Neuman \& Dwyer, 2009, p. 385). Kamil and Hiebert (2005) define vocabulary as knowledge of the meaning of words. According to Hanson \& Padua (2011), the words we use to communicate verbally and in print are referred to as our vocabulary. As a result, vocabulary knowledge is crucial in language learning. Someone who wants to learn English as a second language or as a foreign language should have a good number of vocabularies to be able to use it in social interaction. Thornbury (2004) states that without grammar, very little can be communicated; without vocabulary, nothing can be communicated. This demonstrates that if someone wants to convey meaning, they must have a large vocabulary because if someone knows sentence structure but lacks vocabulary mastery, they will be unable to say or write anything and their grammar knowledge will be useless.

\subsection{Types of Vocabulary}

This section will go over the various types of vocabulary. There are numerous ways to categorize vocabulary types.

1) In terms of semantics:

Milton and Alexiou (2009) divide vocabulary into national words, such as nouns, pronouns, adjectives, numbers, verbs, and adverbs; they name objects, actions, and qualities, among other things. Articles, prepositions, conjunctions, exclamations, and so on are examples of functional words.

2) In terms of communicative language teaching:

Webb (2008) distinguishes between receptive and productive vocabulary. The learners' understanding of vocabulary when they hear or read it is referred to as receptive vocabulary. In other words, the word order that students recognizes when they are listening, speaking, reading, or writing. Understanding of words or phrases in a verbal or written scenario is indicated by receptive vocabulary.

\subsubsection{Types of vocabulary as a list of indicators}

This section describes the types of vocabulary lists

\section{a) Antonyms}

The antonym list has flashcards on one side with one or more words or phrases and antonyms (words with opposite meanings) for those words (in the same language) on the other. This can be used to fully practice vocabulary in the target language as well as to make connections between opposing words in the same context.

\section{b) Pronouns}

The use of pronouns is discouraged in many textbooks, academic writing, and style guides. Pronouns are words that are used to replace a noun after the noun has been mentioned.

\section{c) Collocation}

Collocations are elements that usually accompany words. Consequently, one might argue that because collocation increases the vocabulary knowledge of second language learners in the target language, their acquisition is very important. 
d) Definitions

A flashcard with one or more words on one side and a definition for those words (in the same language) on the other is included in the definition list. This can be used to thoroughly practice vocabulary in the target language.

\subsection{Challenges of Improving Vocabulary Application}

Improving vocabulary mastery is not easy. Many students have difficulty connecting new words. Susanto (2017) says that the factor that affects student learning is characterized by a lack of vocabulary knowledge due to a lack of understanding of its application and meaning. Having an understanding strategy is another challenge in improving their vocabulary mastery. According to Khan (2016), with all of the difficulties or challenges in learning vocabulary, It is likely that it will cause English as a foreign language learners to lose interest and motivation in their studies. In the end, students who learn English will have a low intelligence quotient (IQ).

\subsection{Teaching Vocabulary}

Vocabulary is the first thing people need to master to make sentences or paragraphs. After all, our brains will gain lexical entry through their surroundings, such as listening to the radio, reading books, and listening to the mother tongue (Purnamasari, 2017). In addition, Alber (2010) states that students need to learn words in a context, words do not stand alone, by including the words coming and going every week. Teachers need to teach vocabulary to students in various ways. So, students will be able to understand more than memorize them. For Nation and Meara (2001), students need to develop vocabulary in various contexts to remember them and develop an understanding of the use of a particular word.

Teachers need to teach vocabulary in a fun way, because: (1) Using interesting and fun activities can develop students' interest and help them both memorize and remember (Asyiah, 2017). (2) The idea is smart because students like to play so that learning and understanding vocabulary does not become stressful (Bakhsh, 2016). (3) Fun teaching will increase student motivation. In addition, various studies have shown that games are useful for increasing student motivation (Derakshan \& Khatir, 2015). (4) Fun teaching must also be considered by teachers and game discussions can help teachers create useful and meaningful contexts (Derakshan \& Khatir, 2015).

In addition, Khaisaeng and Dennis (2017) concludes that parts of speech fall into eight categories: nouns, pronouns, verbs, adverbs, adjectives, prepositions, determiners, and conjunctions help students read the weekly online student magazine. This means that the part of speech used can be said to be an indicator of vocabulary.

\subsection{Teaching Vocabulary through Memrise Application}

Memrise is a free language learning platform. The user uses for communities to teach and improve language learning for everyone who is involved in using this application. Memrise has several unique features. One of the features of this application is the Memrise exercise system. This system can train and store a strong memory in the brain. Just like this system combined with flashcards and games, it makes learners fun in learning languages, especially vocabulary.

Here are some types of activities in Memrise that are useful in learning, such as: 
1. The first activity is learning words or phrases. This application will provide practices for the learners in the form of multiple-choice words or phrases that have been studied. By clicking the multiple-choice exercises, the students aimed to reach the specified target.

2. The next exercise is arranging words or phrases. In this phase, the learners compose sentences consisted of words. The learners are challenged to create their original sentences not phrases in the target language. When they have completed, the teacher as the researcher evaluates their work.

3. Then students memorize the words that they have learned quickly. Besides that, they challenge themselves with difficult words to see their abilities how much they can achieve as in score. Memrise has a variety of features, including audio, visual, and media on video. Karjo and Andreani (2018) categorize the challenges features or items used for the Memrise into five categories such as translation of words, word flashcards, audio choices challenge, typing questions, and phrase translation.

\section{Translation of Words}

The most basic question on the Memrise app is the translation of words. In this section, Memrise has four to six answer boxes. The person who uses should select an answer box that has the same meaning as the question word. If the user answers correctly, Memrise will display a large alert.

\section{Word Flashcards}

The flashcard has several items on the list. The item was created to help the user recall a previously learned word. After the word translation challenges, a flashcard will appear. To remember the word, the user can type anything into the flashcard. Memrise does not always assist users in creating flashcards; as a result, users are required to perform two tasks: create their flashcards and memorize new words on their own. In practice, many users avoid creating a flashcard.

\section{Audio Choices Challenge}

For this challenge, Memrise provides three audio options. Users of Memrise will be asked to select one of the audio options based on the question word. To respond to that question, users can listen to the audio by clicking on it one at a time. In addition, the correct answers should be chosen by the user and then press the "next" button. The answer key is then displayed to the Memrise user immediately, the correct answer is indicated by green color, while the incorrect answer is indicated by a red color.

\section{Word Typing Test}

Memrise will help the user improve their listening skills. In this section, Memrise users hear from audio voice, then they type any words they hear. For example, when the user hears the word tea, they should type tea into the answer field.

\section{Translation of Phrases}

Memrise will present the user with a phrase of words in the form of a question. Following the question, there are five answer options, each with a different translation and consisting of a word from each answer. The user must select the correct one that has the same meaning as the question. After this challenge section, Memrise will always ask the user to create a flashcard to help them remember the phrase. 


\subsection{Teaching Vocabulary Through Google Classroom}

Google Classrooms enable teachers to quickly create and organize assignments, provide effective feedback, and communicate with their students. There are numerous advantages to online or blended learning styles over traditional classroom teaching styles. Free accessibility, scheduling flexibility for students, and adaptability to work are the most significant benefits of Google Classroom (Brown \& Hocutt, 2015). It considers the accomplishment of specific functions, such as improving student-teacher communication and making assignment distribution and assessment easier. This enables students to submit their work for online assessment by their teacher within a set deadline. Similarly, teachers can see the entire picture of each student's progress and return work with necessary comments, allowing students to revise their assignments. This application makes it easier for teachers and students to implement a deeper learning process. This is because teachers and students can collect, distribute, and grade assignments without being constrained by lesson deadlines.

\section{Research Method}

This research employs a quantitative research design with a comparative design. Quantitative research focuses on objective measurement and statistical, mathematical, or numerical analysis of data collected via pretest and posttest design by using a computer to manage statistical data.

The instrument of the study was pilot tested to see its validity and reliability. The result of the validity and the reliability of the instrument was categorized as high. Anatest software program was used to analyze the data. Since the result of the data showed high validity and reliability then it was used as the pre and post-test.

The study was carried out for three months at SMP Kristen Kalam Kudus III, Jakarta to the eighth-grader students or second year. The students and the teacher/researchers met in an online class through Google Meet twice a week. Meeting through Google Meet online for an hour and another hour the students spent their time doing the activities assigned to them in the Google Classroom.

Students were given a pre-test before treatment and a post-test after treatment by the researcher. The goal was to observe and quantify the increase in vocabulary enhancement of students using the Memrise and Google Classroom. 40 students in the experimental group were taught using Memrise in the Google Meet and doing the activities and uploaded their homework and their result was through Google Classroom. The researcher used these two classes to apply the same treatment and the same strategy. The students were assorted into two groups, with those two groups there were 20 female and 20 male students. This research discovered a significant difference in the vocabulary enhancement of students who were taught using the Memrise and Google Classroom in females and those who were taught using the Memrise and Google Classroom in males.

The researchers used pre-test and post-test to obtain data. Pre-test and post-test were conducted online for both groups using the same strategy. Both classes were using Google Meet, Memrise, and Google Classroom in the female and male groups. The study was done for 12 weeks. The class was conducted online using Google Meet and the homework and other activities of the students' were done in Google Classroom. 
Vocabulary Enhancement through Memrise \& Google Classroom, Stephanie Feli Taebenu, Caroline Victorine Katemba

\section{Results and Discussion}

In data collection, the researchers conducted a 'pilot test' to determine the validity and reliability of the instrument. The researchers used the Anatest program to calculate the validity and reliability. The calculation results obtained a validity value of 0,88 , which meant the test was valid. While the reliability value was 0,92 , meaning that the test was reliable. Please refer to Tables $1 \& 2$.

Table 1. The Criteria for Coefficient Correlation (Validity)

\begin{tabular}{cc}
\hline Rxy & Interpretation \\
\hline $0.81-1.00$ & Very High \\
$0.61-0.80$ & High \\
$0.41-0.60$ & Moderate \\
$0.21-0.40$ & Low \\
$0.00-0.20$ & Very Low \\
$\leq 0.00$ & Not Valid \\
\hline
\end{tabular}

Table 2. The Criteria for Reliability

\begin{tabular}{cc}
\hline Coefficient Reliability & Interpretation \\
\hline$r 11<0.20$ & Very Low \\
$0.20<r 11 \leq 0.40$ & Low \\
$0.40<r 11 \leq 0.70$ & Moderate \\
$0.70<r 11 \leq 0.90$ & High \\
$0.90<r 11 \leq 1.00$ & Very High \\
\hline
\end{tabular}

The pilot test results allowed the researchers to select all of the valid and reliable items to be used for the instrument-the vocabulary test, which were used as a pre-test before the program and a post-test was administered at the end of the program. Following the collection of the pretest data, the data were analyzed using SPSS 25.0 to calculate the data analysis, which included the Gain, Normality test, Homogeneity test, and Mann-Whitney Non-Parametric Test.

The researchers calculated the pre-test, post-test, and normalized gain of each class when analyzing the data, as shown in table 3.

Table 3. The Pre-Test, Post-Test, Standard Deviation, and Normalized Gain Result

\begin{tabular}{lcccc}
\hline & \multicolumn{3}{c}{ Female } & \multicolumn{2}{c}{ Male } \\
\cline { 2 - 5 } & Mean & St. Dev & Mean & St. Dev \\
\hline Pre-test & 83.7500 & 6.01642 & 80.5000 & 6.62928 \\
Post-test & 95.4000 & 3.16893 & 89.0000 & 6.02626 \\
Normalized & .7291 & .12606 & .4663 & .20671 \\
Gain & & & & \\
\hline
\end{tabular}

Table 3 showed that the mean pre-test of the female group is 83.7500 with a standard deviation of 6.01642 and the mean post-test was 95.4000 with a standard deviation of 3.16893. The male group had a pre-test mean of 80.5000 with a standard deviation of 
6.62928 and a post-test mean of 89.0000 with a standard deviation of 6.02626 . Normalized gain for the female group was 0.7291 and for the male group is 0.4663 , indicating that there was an improvement in students' vocabulary.

The normality test was used to determine whether or not the data population was normally distributed. The normality result is shown in table 4.

Table 4. Result of Normality Test

\begin{tabular}{cccc}
\hline Group & Statistic & $\begin{array}{c}\text { Shapiro-Wilk } \\
\mathrm{df}\end{array}$ & Sig \\
\hline $\begin{array}{c}\text { Pre-test } \\
\text { (Female) }\end{array}$ & .881 & 20 & .018 \\
$\begin{array}{c}\text { Post-test } \\
\text { (Female) }\end{array}$ & .755 & 20 & .000 \\
$\begin{array}{c}\text { Pre-test } \\
\text { (Male) }\end{array}$ & .918 & 20 & .091 \\
$\begin{array}{c}\text { Post-test } \\
\text { (Male) }\end{array}$ & .915 & 20 & .081 \\
\hline
\end{tabular}

The criteria for normality, if the sig. value was greater than 0,05 , the data were normally distributed. Otherwise, if the sig. value was less than 0,05 , which indicated that the data were not normally distributed. According to the normality test calculation, the female group's pre-test score was not normally distributed, whereas the male group's score was normally distributed, with the significant value of the female group's result being $0,018<$ 0,05 and the significant value of the male group's result being $0,091>0,05$. The pretest result revealed that male significant values were greater than female significant values. Similarly, the post-test for the female group was not normally distributed, whereas the male group was normally distributed, as evidenced by the female group's score of $0,000<0,05$ and the male group's score of $0,081>0,05$. It was possible to conclude that all of the data for the female group were not normally distributed, whereas all of the data for the male group were normally distributed.

The researchers did the homogeneity test after knowing the normality, to see whether the populations were homogenous or not. The homogeneity test was used to determine the homogeneity of population variances. Table 5 displays the results of the homogeneity test.

Table 5. Result of Homogeneity Test

\begin{tabular}{|c|c|c|c|c|c|}
\hline \multicolumn{6}{|c|}{ Test of Homogeneity of Variance } \\
\hline & & Levene Statistic & df1 & df2 & Sig. \\
\hline \multirow[t]{4}{*}{ Students' score } & Based on Mean & 10.537 & 1 & 38 & .002 \\
\hline & $\begin{array}{l}\text { Based on } \\
\text { Median }\end{array}$ & 7.553 & 1 & 38 & .009 \\
\hline & $\begin{array}{l}\text { Based on } \\
\text { Median and } \\
\text { with adjusted df }\end{array}$ & 7.553 & 1 & 31.618 & .010 \\
\hline & $\begin{array}{l}\text { Based on } \\
\text { trimmed mean }\end{array}$ & 10.514 & 1 & 38 & .002 \\
\hline
\end{tabular}


Vocabulary Enhancement through Memrise \& Google Classroom, Stephanie Feli Taebenu, Caroline Victorine Katemba

Based on the result, the Sig. Based Mean was 0,002 <0,05, indicating that the data variants of the female post-test and the male post-test were not homogeneous.

Since the data population in one group of students was not normally distributed, NonParametric Test or Mann-Whitney Test was conducted and the result is depicted below.

Table 6. The Mann-Whitney Test Result for Post-test Score

\begin{tabular}{lc}
\hline & Learning Outcomes \\
\hline Mann-Whitney U & 77.000 \\
Wilcoxon W & 287.000 \\
Z & -3.416 \\
Asymp. Sig. (2-tailed) & .001 \\
Exact Sig. [2*(1-tailed Sig.)] & $.001 \mathrm{~b}$ \\
\hline
\end{tabular}

The criteria for Mann-Whitney, if the value of Asymp.Sig. $<0,05$ it means that the null hypothesis is rejected. Otherwise if the value of Asymp.Sig. $>0,05$ it means that the null hypothesis is accepted. Based on the calculation, it showed that the Asymp.Sig. (2 tailed) was $0,001<0,05$. So, it can be concluded that the null hypothesis is rejected and the alternative hypothesis which is the $\mathrm{Ha}$ is accepted. Thus it can be concluded that there are significant differences in learning outcomes using Memrise application between females and males. Because there is a significant difference, it can be said that "there is an effect of using the Memrise application on the learning process to improve vocabulary enhancement". Another result shows that female groups have higher attainment in this study. The use of Memrise, could enhance both the female and male's vocabulary but the female has higher attainment.

\section{Conclusion}

The results of the data analysis reveal that both groups have improved their vocabulary. It shows from the pre-test of the female group mean score is 83.7500 and has increased to 95.4000 while the pre-test in the male group's mean score is 80.5000 and has increased to 89.0000. Both groups indicate that there is an increase in vocabulary enhancement but, the female group result shows a significantly higher enhancement compared to the male group. That has answered the research question on "Which group among the female and the male group has a higher vocabulary enhancement score? So, it can be said that the Memrise application is more applicable in the female group because the value score of the female is higher than the male. It can be concluded that these strategies have positive results since the strategies are increasing in enhancing the students' vocabulary.

This study is supported by several researchers who had a study on Memrise too. Affandi \& Syafi'I (2018) conducting a study entitled "Memrise as A Builder of Students Vocabulary" proved that Memrise was effective to improve students' knowledge, especially for learning new vocabulary. Fathi et al., (2018) "Enhancing Vocabulary Learning and Self-Regulation via a Mobile Application: An Investigation of the Memrise App" proved that the use of Memrise improved students' self-regulated capacity in vocabulary learning, which deeply connected to learner motivation and played a great role in making releasers self-regulated. Abarghoui \& Taki (2018) "Measuring the Effectiveness of Using "Memrise" on High School Students' Perceptions of Learning EFL" and the result was the use of Memrise made students more interested, making students more confident and positive, more focused on doing the quiz. Another study was done by Fadhilawati (2016) on "Learning and Reviewing Vocabulary 
Through Memrise to Improve Students' Vocabulary Achievement" and the result indicated that learning and reviewing vocabulary through Memrise could improve the students' vocabulary achievement. Izah (2019) "Upgrading Students' Vocabulary Through "Memrise" App" indicated that using Memrise made students feeling more enjoyable in learning vocabulary and found that it was easy to use the Memrise.

In addition, to respond to the research question, "Is there any significant difference in students' vocabulary enhancement between female and male after being taught using Memrise?", The answer to this question shows that there is a significant difference between female and male in using Memrise application, proved from the Mann-Whitney scores: $0,001<0,05$. To sum up, the Memrise application can enhance students' vocabulary between females and males and it is effective.

\section{References}

Abarghoui, M. A., \& Taki, S. (2018). Measuring the Effectiveness of Using "Memrise" on High School Students' Perceptions of Learning EFL. Theory and Practice in Language Studies, 8(12), 1758. https://doi.org/10.17507/tpls.0812.25

Abid Azhar, K., \& Iqbal, N. (2018). Effectiveness of Google Classroom: Teachers' Perceptions. Prizren Social Science Journal, 2(2), 52-66.

Abrams, S.S. \& Walsh, S. (2014). Gamified Vocabulary: Online Resources and Enriched Language Learning. Journal of Adolescent \& Adult Literacy, 58(1), 49-58. Retrieved from: https://ila.onlinelibrary.wiley.com/doi/abs/10.1002/jaal.315

Affandi, M. H., \& Syafi'i, A. (2018). Memrise as a Builder Students Vocabulary. Efektor, 5(1), 32-38. https://doi.org/10.29407/e.v5i1.11921

Aisyah, N. S., Hidayatur Rahma, N. A., \& Yugafiati, R. (2019). Improving Student's Vocabulary Mastery through Cooperative Script on Descriptive Text. Project (Professional Journal of English Education), 2(2), 181.

Alber, R. (2010). Doing It differently: Tips for Teaching Vocabulary. [Online]. Retrieved from: https://www.researchgate.net/publication/330685107_Usefulness_and_Learnability _in_Teaching_Vocabulary_to_ESLEFL_Students

Aminatun, D., \& Oktaviani, L. (2019). Memrise: Promoting Students' Autonomous Learning Skill through Language Learning Application. Metathesis: Journal of English Language, Literature, and Teaching, 3(2), 214. https://doi.org/10.31002/metathesis.v3i2.1982

Asyiah, D. N. (2017). The Vocabulary Teaching and Vocabulary Learning: Perception, Strategies, and Influences on Students' Vocabulary Mastery. Jurnal Bahasa Lingua Scientia, 9(2), 293-318. https://doi.org/10.21274/ls.2017.9.2.293-318

Bakhsh, S. A. (2016). Using Games as a Tool in Teaching Vocabulary to Young Learners. English Language Teaching, 9(7), 120. https://doi.org/10.5539/elt.v9n7p120

Beglar, D., \& Hunt, A. (2005). Six Principles for Teaching Foreign: A Commentary on Laufer, Meara, and Nation"s "Ten Best Ideas." In The Language Teacher, 29(7), 7-10.

Berliani, N. A., \& Katemba, C. V. (2021). The Art of Enhancing Vocabulary through Technology. Jurnal Smart, 7(1), 35-45. https://ejournal.umpri.ac.id/index.php/smart/article/view/1340

Boyle, J. P. (1987). Sex Differences in Listening Vocabulary. Language Learning, 37(2), 273284.

Brown, M. E., \& Hocutt, D. L. (2015). Learning to Use, Useful for Learning: A Usability Study of Google Apps for Education. Journal of Usability Studies, 10(4), 160-181. http://www.upassoc.org. 
Vocabulary Enhancement through Memrise \& Google Classroom, Stephanie Feli Taebenu, Caroline Victorine Katemba

Catalán, R. M. J. (2003). Sex differences in L2 Vocabulary. International Journal of Applied Linguistics, 13(1), 54-77. http://doi.wiley.com/10.1111/1473-4192.00037

Chun, D., Kern, R., \& Smith, B. (2016). Technology in Language Use, Language Teaching, and Language Learning. The Modern Language Journal, 100(S1), 64-80. doi:10.1111/modl.12302

Derakhshan, A., \& Khatir, E.D. (2015). The Effects of Using Games on English Vocabulary Learning. Journal of Applied Linguistics and Language Research, 2(3), 39-47. Retrieved

from:https://pdfs.semanticscholar.org/774c/2cae6b8aefbe2fdcf88c151d0441bebba8 57.pdf

Fadhilawati, D. (2016). Learning and Reviewing Vocabulary through Memrise to Improve Students' Vocabulary Achievement. Journal of Academic Research and Sciences (JARES), 1(2), 4. https://doi.org/10.30957/jares.v1i2.419

Fathi, J., Alipour, F., \& Saeedian, A. (2018). Enhancing Vocabulary Learning and Selfregulation via a Mobile Application: An Investigation of the Memrise App. Journal of Modern Research in English Language Studies, 5(1), 27-46.

Giessen, H. (2019). An Explorative Study on Media Effects in Vocabulary Learning. Lublin Studies in Modern Languages and Literature, 43(4), 147.

Hanson, S., \& Padua, J. F. M. (2011). Teaching Vocabulary Explicitly. Pacific Resources for Education and Learning, $10 . \quad$ https://www.prel.org/wpcontent/uploads/2014/06/vocabulary_lo_res.pdf

Iftakhar, S. (2016). Google Classroom: what Works and How?. Journal of Education and Social Sciences, Vol. 3, pp. 12-18.

Indrasari, A., Novita, D., \& Megawati, F. (2018). Big Book: Attractive Media for Teaching Vocabulary to Lower Class of Young Learners. Jees (Journal of English Educators Society), 3(2), 141.

Izah, N. (2019). Upgrading Students' Vocabulary through "Memrise" App. Proceeding of First Conference of English Language and Literature (CELL), 2019, 1-10.

Kamil, L. M., \& Hiebert, H. L. (2005). Teaching and Learning Vocabulary Perspective and Persistent Issues. Journal Laurance Erlbaum Associates: LondonKey to Long-Term Reading Success. USA: Houghton Mifflin Company

Kapp, K. M. (2012). The Gamification of Learning and Instruction: Game-based Methods and Strategies for Training and Education. San Francisco, CA: Pfeiffer.

Karjo, C. H., \& Andreani, W. (2018). Learning Foreign Languages with Duolingo and Memrise. ICDEL, 109-112. doi:10.1145/3231848.3231871

Katemba, C. V., (2021). Enhancing Vocabulary Performance through Mobile Assisted Language Learning at a Rural School in Indonesia. Acuity: Journal of English Language Pedagogy, Literature, and Culture, 6(1), 1-11. https://doi.org/10.35974/acuity.v6i1.2457

Katemba, C., V. (2019). Students' Vocabulary Enhancement at Grade 10: A Comparative Study Using CALL \& MALL in Indonesia. CALL-EJ, 20(1), 87-114. http://callej.org/journal/20-1/Katemba2019.pdf

Katemba, C.V., Sianipar, E.,J., (2020). Students' Vocabulary Enhancement in Grade V, A Comparative Study Using Total Physical Response Storytelling and Jigsaw IV, Human Behaviour Development and Society, 21(2). https://so01.tcithaijo.org/index.php/hbds/article/view/156406 
Khaisaeng, S. \& Dennis, N.K. (2017). A Study of Part of Speech Used in Online Student Weekly Magazine. International Journal of Journal of Research Granthaalayah, 5(4), 43-50.

Khan, I. A. (2016). Difficulties in Mastering and Using English for Specific Purpose (Medical Vocabulary): A Linguistic Analysis of Working Saudi Hospital Professionals. International Journal of Education, 8(1), 78. https://doi.org/10.5296/ije.v8i1.9163

Korlu, H., \& Mede, E. (2018). Autonomy in vocabulary learning of Turkish EFL learners. The EUROCALL Review, 26(2). https://doi.org/10.7748/paed.8.2.29.s25

Krashen, S., \& Terrell, T. (1983). The Natural Approach (p. 191). (1st ed). New York: PrenticeHall.

Łuczak, A. (2017). Using Memrise in Legal English Teaching. Studies in Logic, Grammar, and Rhetoric, 49(1), 141-152.

Mehrabian, N., Salehi, H., \& Branch, N. (2019). The Effects of Using Diverse Vocabulary Learning Strategies on Word Mastery: A Review. Journal of Applied Studies In Language, 3(1), 100-114.

Milton J., \& Alexiou, T. (2009) Vocabulary Size and the Common European Framework of Reference for Languages. In: Richards B., Daller M.H., Malvern D.D., Meara P., Milton J., Treffers-Daller J. (eds) Vocabulary Studies in First and Second Language Acquisition. London: Palgrave Macmillan. https://doi.org/10.1057/9780230242258_12

Muntean, C. I. (2011). Raising Engagement in E-Learning through Gamification. 6 th $^{\text {th }}$ international conference on virtual learning (pp. 323-329).

Nation, P., \& Meara, P. (2002). Vocabulary. In N. Schmitt (Ed.), An Introduction to Applied Linguistics. London: Arnold.

Natsir, Y., Yusuf, Y. Q., \& Huri, A. D. (2016). The Male and Female EFL Students' Language Learning Styles. Paper presented at the Proceedings of the First Reciprocal Graduate Research Symposium between University Pendidikan Sultan Idris and Syiah Kuala University (pp. 66-73). Banda Aceh.

Neuman, S. B., \& Dwyer, J. (2009). Missing in Action: Vocabulary Instruction in Pre-K. The Reading Teacher, 62(5), 384-392. Retrieved from: https://www.researchgate.net/publication/228632895

Ning, W. (2017). Student's Responses in Enhancing New Vocabulary through Subtitles English Mobile. Jakarta: Universitas Advent Indonesia. Retrieved from: https://doi.org/10.35974/acuity.v3i1.623

Nolan, J., \& McBride, M. (2014). Beyond Gamification: Reconceptualizing Game-Based Learning in Early Childhood Environments. Information, Communication \& Society, 17(5), 594-608.

Nunan, D. (1991). Language teaching Methodology a Textbook for the Teacher. (1st ed.). Prentice-Hall.

Nurdiansyah, D. M. R., Asyid, S. A., \& Parmawati, A. (2019). Using Color Coding To Improve Students' English Vocabulary Ability. PROJECT (Professional Journal of English Education), 2(3), 358. https://doi.org/10.22460/project.v2i3.p358-363

Prensky, M. (2001). Digital Natives, Digital Immigrants: Part 1. On the Horizon, 9(5), 1-6.

Purnamasari, R.L. (2017). Developing Teaching Material to Support Reading Skill through "Hyponymy games". (Unpublished research)

Rumondor, G.O. (2017). The Effectiveness of Using Total Physical Response Story Telling to Enhance Students' Vocabulary. Universitas Advent Indonesia. Retrieved from: https://jurnal.unai.edu/index.php/index/login?source=\%2Findex.php\%2Findex\%2Fart icle\%2Fview\%2F1541 
Vocabulary Enhancement through Memrise \& Google Classroom, Stephanie Feli Taebenu, Caroline Victorine Katemba

Sari, L. I., \& Sutopo, D. (2018). The Effectiveness of Vocabulary Self-Collection and Word Mapping Strategies for Teaching Vocabulary to Maritime Cadets with High and Low Metacognitive Awareness. English Education Journal, 8(1), 35-42.

Susanto, A. (2017). The Teaching of Vocabulary: A Perspective. Jurnal KATA, 1(2), 182. https://doi.org/10.22216/jk.v1i2.2136

Thornbury, S. (2004). How to Teach Vocabulary. Asian EFL Journal |. March, 1-5.

Webb, S. (2008). Receptive and Productive Vocabulary Sizes of L2 Learners. Studies in Second Language Acquisition, 30(1), 79-95. Retrieved May 27, 2021, from http://www.jstor.org/stable/44488020

Wei, N. (2016). Gender Differences in the Use of English Vocabulary Learning Strategies in Chinese Senior High Schools. Studies in Literature and Language, 12(4), 58-62. https://doi.org/10.3968/8225

Widyaningrum, N., \& Putro, N. H. P. S. (2020). Using Memrise to Promote students' Listening and Speaking Abilities. Teacher Education and Professional Development in Industry 4.0 - Ashadi et al. (eds), 350-352. London, LDN: Taylor and Francis Group.

Zoghi, M., Kazemi, S. A., \& Kalani, A. (2013). The Effect of Gender on Language Learning. Journal of Novel Applied Sciences, 2(S4), 1124-1128. 